\title{
Baseline Assessment of Physical Characteristics, Aquatic Biota, and Selected Water-Quality Properties at the Reach and Mesohabitat Scale for Three Stream Reaches in the Big Cypress Basin, Northeastern Texas, 2010-11
}

To help sustain aquatic biota, environmental flows are increasingly being established (prescribed) for streams throughout the United States. Environmental flows are agreed upon streamflows established to sustain aquatic biota and other organisms that rely on a healthy riverine ecosystem, and these streamflows often vary on a seasonal basis. In the Big Cypress Basin in Texas, environmental flows are prescribed as part of the Sustainable Rivers Project (SRP), a partnership between the U.S. Army Corps of Engineers (USACE) and the Nature Conservancy with input and oversight provided by the Texas Commission on Environmental Quality. Implementation details are handled at the local level. For example, the USACE and Northeast Texas Municipal Water District are working together to determine the best strategy to implement prescribed environmental flows for Big Cypress Bayou downstream from the Lake O' the Pines, which is managed by USACE (fig. 1). The goal of the SRP is to alter existing operations at USACE dams in order to enhance habitat conditions for animals and plants that depend on flows downstream from the dams by returning flows to a more natural flow regime. The SRP is active in eight river basins across the United States, including Big Cypress Bayou (Konrad, 2010).

The U.S. Geological Survey (USGS), in cooperation with the Northeast Texas Municipal Water District and the Texas Commission on Environmental Quality, did a baseline assessment in 2010-11 of physical characteristics and selected aquatic biota (fish and mussels) collected at the mesohabitat scale for three stream reaches in
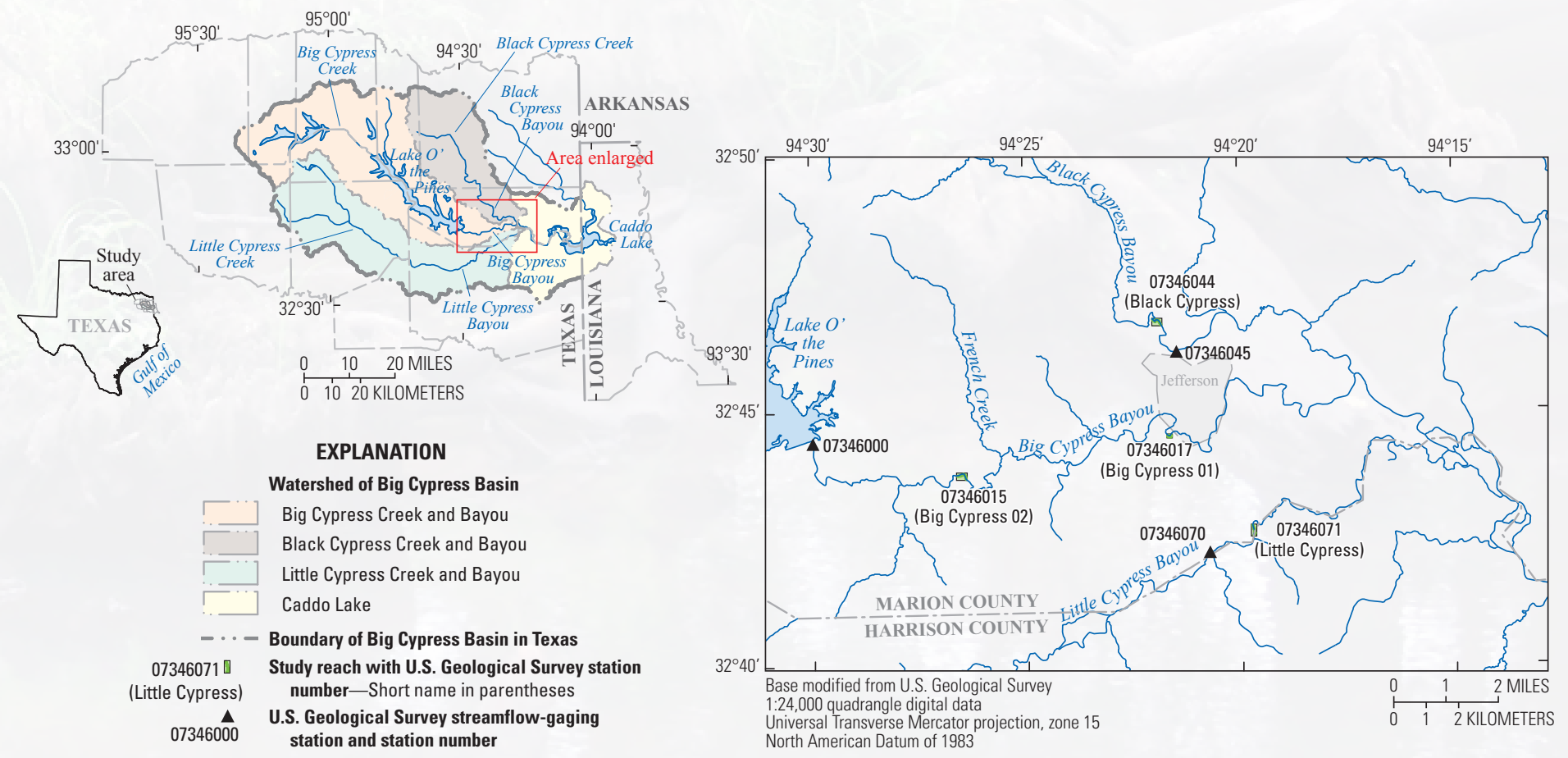

Figure 1. Location of study area, Big Cypress Basin, northeastern Texas. 


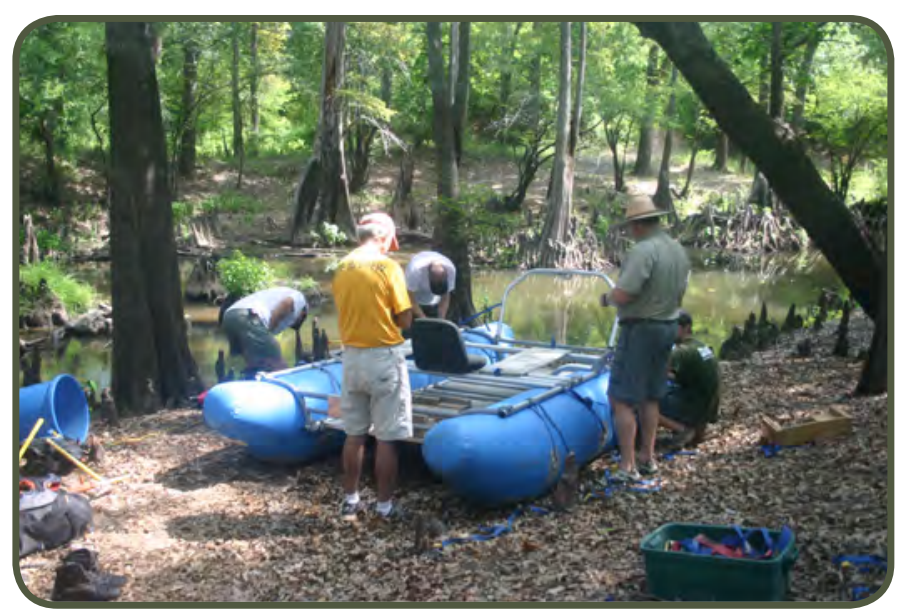

U.S. Geological Survey scientists assembling cataraft for collecting fish from Big Cypress Creek, Texas, July 27, 2011. Photograph taken by Erin C. Sewell, U.S. Geological Survey.

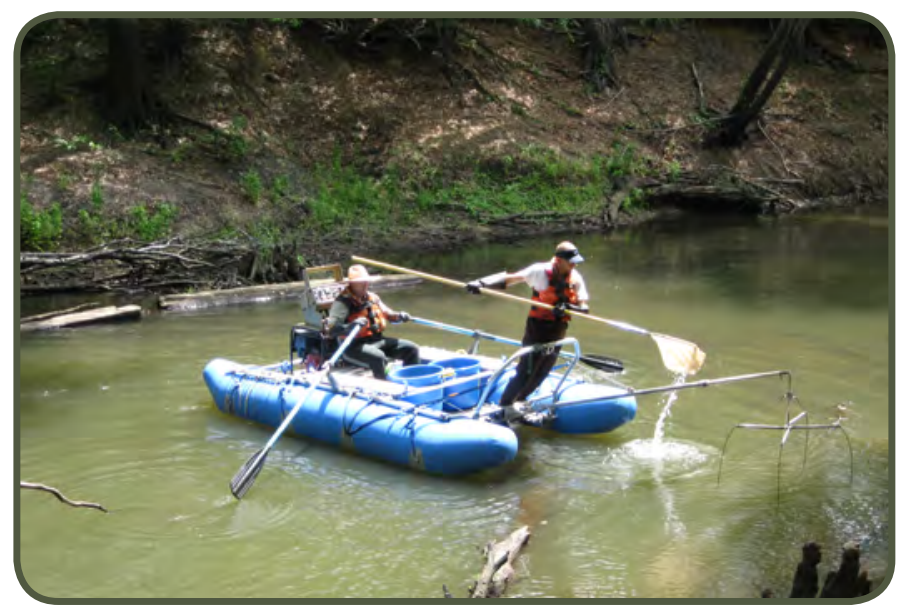

U.S. Geological Survey scientists collecting fish from Big Cypress Creek, Texas, July 27, 2011. Photograph taken by Justin A. McInnis, U.S. Geological Survey. the Big Cypress Basin in northeastern Texas for which environmental flows have been prescribed. Mesohabitats are visually distinct units of habitat within the stream (Pardo and Armitage, 1997) with unique depth, velocity, slope, substrate, and cover. Mesohabitats in reaches of Big Cypress, Black Cypress, and Little Cypress Bayous (fig. 1) were evaluated to gain an understanding of how fish communities and mussel populations varied by habitat. Selected water-quality properties were also measured in isolated pools in Black Cypress and Little Cypress. All of the data were collected in the context of the prescribed environmental flows. The information acquired during the study will support the long-term monitoring of biota in relation to the prescribed environmental flows (table 1).

Biological and physical characteristic data were collected during a period of low flow in July-August 2010 and a period of very low flow in July 2011 from two sites on Big Cypress Bayou, and one site on both Black Cypress Bayou and Little Cypress Bayou. The upstream reach of Big Cypress Bayou is referred to as the Big Cypress 02 site. The downstream site on Big Cypress Bayou is referred to as the Big Cypress 01 site and was sampled exclusively for mussels (fig. 1).

Differences in physical characteristics such as stream width and depth can affect the abundance and variety of the fish and mussels in a stream. The widths and depths of the stream varied appreciably where physical habitat data were collected in 2010. The reach at the Big Cypress 02 site was the widest and deepest, with a mean width of 62.2 feet (ft) and a mean depth of $5.5 \mathrm{ft}$ in main-channel mesohabitats. The reach at the Black Cypress site was the narrowest of the three reaches, with a mean width of $29.1 \mathrm{ft}$ and a mean depth of $3.3 \mathrm{ft}$ in main-channel mesohabitats.

Table 1. Prescribed environmental flows (in cubic feet per second) for Big Cypress Bayou, Black Cypress Bayou, and Little Cypress Bayou based upon a variety of ecological objectives during dry and average years (Caddo Lake Institute, 2010).

\begin{tabular}{|c|c|c|c|c|c|c|c|c|c|c|c|c|}
\hline & Jan. & Feb. & Mar. & Apr. & May & June & July & Aug. & Sept. & 0ct. & Nov. & Dec. \\
\hline Dry year & \multicolumn{2}{|c|}{ Fish habitat } & \multicolumn{4}{|c|}{ Spawning habitat } & \multicolumn{3}{|c|}{ Maintain aquatic diversity } & \multicolumn{3}{|c|}{ Fish habitat } \\
\hline Big Cypress Bayou & 90 & 90 & 218 & 198 & 114 & 49 & 13 & 6 & 6 & 40 & 90 & 90 \\
\hline Black Cypress Bayou & 125 & 201 & 242 & 140 & 80 & 42 & 11 & 4 & 4 & 4 & 19 & 91 \\
\hline Little Cypress Bayou & 112 & 186 & 219 & 158 & 86 & 38 & 12 & 5 & 5 & 5 & 18 & 68 \\
\hline Average year & \multicolumn{2}{|c|}{ Fish habitat } & \multicolumn{4}{|c|}{ Benthic drift and dispersal, fish spawning } & \multicolumn{3}{|c|}{ Fish habitat } & \multicolumn{3}{|c|}{ Fish habitat } \\
\hline Big Cypress Bayou & 268 & 347 & 390 & 330 & 150 & 79 & 35 & 40 & 40 & 40 & 90 & 117 \\
\hline Black Cypress Bayou & 222 & 300 & 306 & 205 & 156 & 95 & 32 & 5 & 4 & 13 & 74 & 209 \\
\hline Little Cypress Bayou & 242 & 471 & 415 & 287 & 155 & 96 & 26 & 10 & 10 & 19 & 65 & 144 \\
\hline
\end{tabular}


Appreciably more fish were collected from Big Cypress 02 (596) in summer 2010 compared to Black Cypress (273) or Little Cypress (359), but the total number of fish species collected among the three reaches was similar (fig. 2). Longear sunfish was the most abundant fish species collected from all three streams. In all three streams, there were far more fish species in the runs than in the pools. The total number of fish species was largest in slow run mesohabitats at Big Cypress 02, fast runs at Black Cypress, and slow runs at Little Cypress.

Fish counts were standardized by determining the catch-per-unit-effort as the number of fish collected in 30 seconds of electrofishing. The catch per unit effort of native minnows was largest in fast runs at Big Cypress 02.

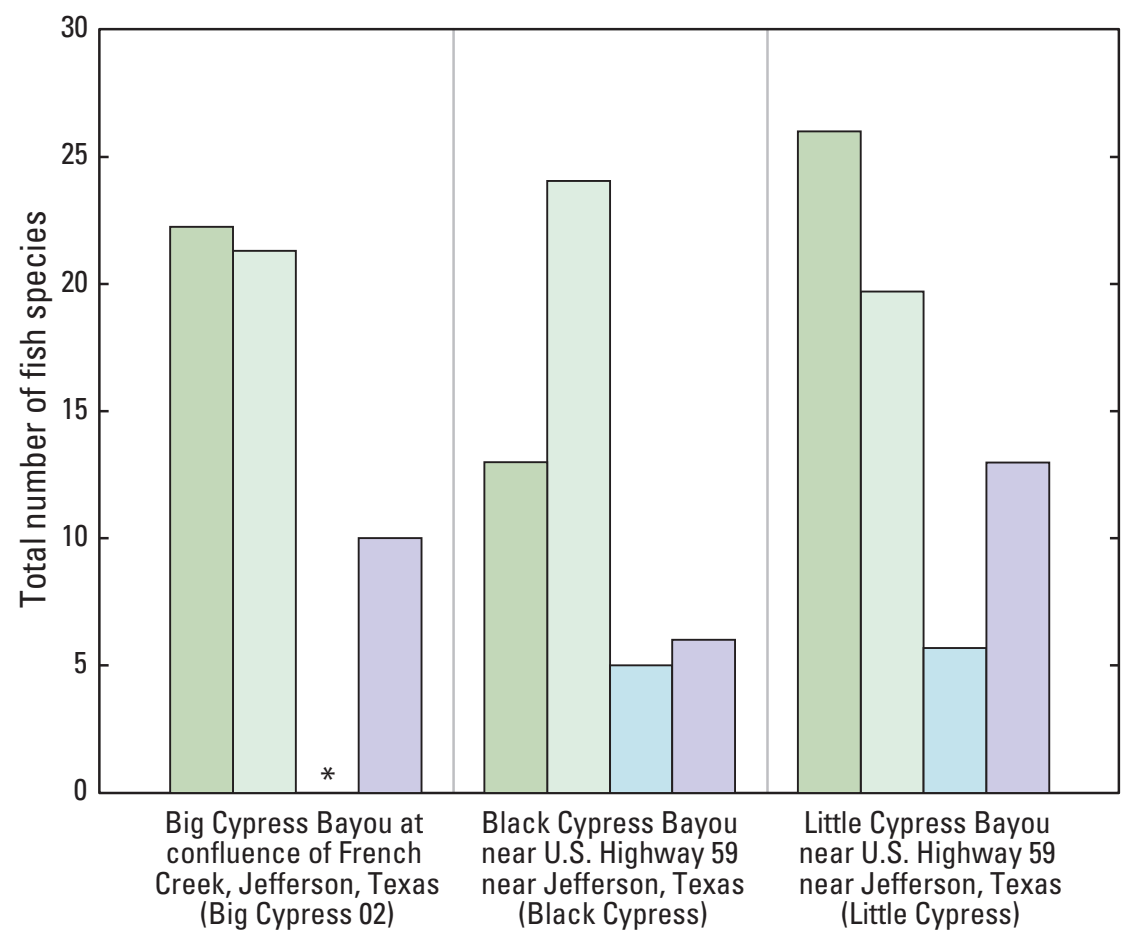

\section{EXPLANATION}

Mesohabitat type

\begin{tabular}{|ll}
\hline & Slow runs \\
\hline & Fast runs \\
\hline & Channel pools \\
\hline & Margin pools
\end{tabular}

* Mesohabitat type not present.

Figure 2. Number of fish species collected by mesohabitat type from sites on Big Cypress Bayou, Black Cypress Bayou, and Little Cypress Bayou in the Big Cypress Basin in northeastern Texas, 2010-11.

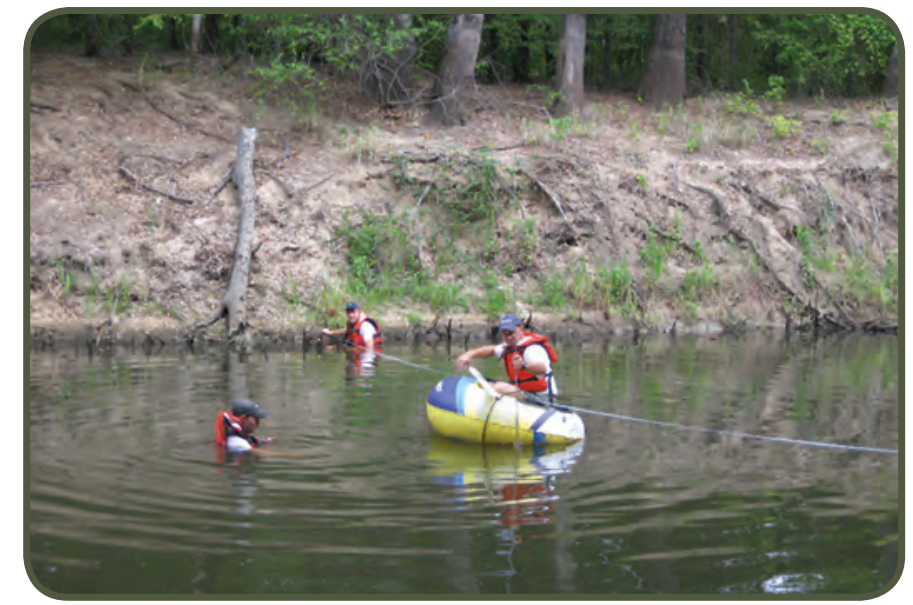

U.S. Geological Survey scientists measuring physical characteristics of Big Cypress Creek, Texas, July 26, 2011. Photograph taken by James B. Moring, U.S. Geological Survey

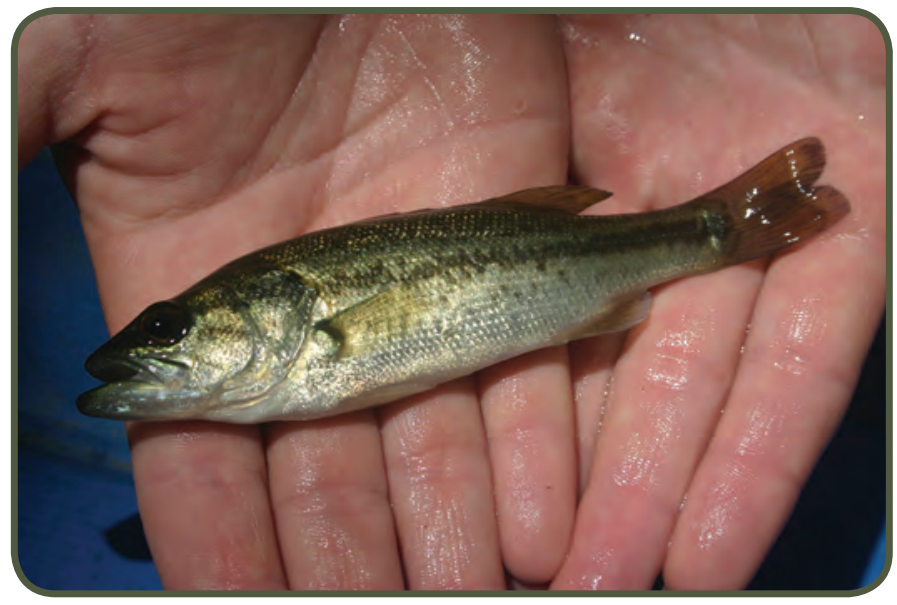

Typical size largemouth bass collected at the upstream reach of Big Cypress Bayou (Big Cypress 02), Texas, July 2010. 


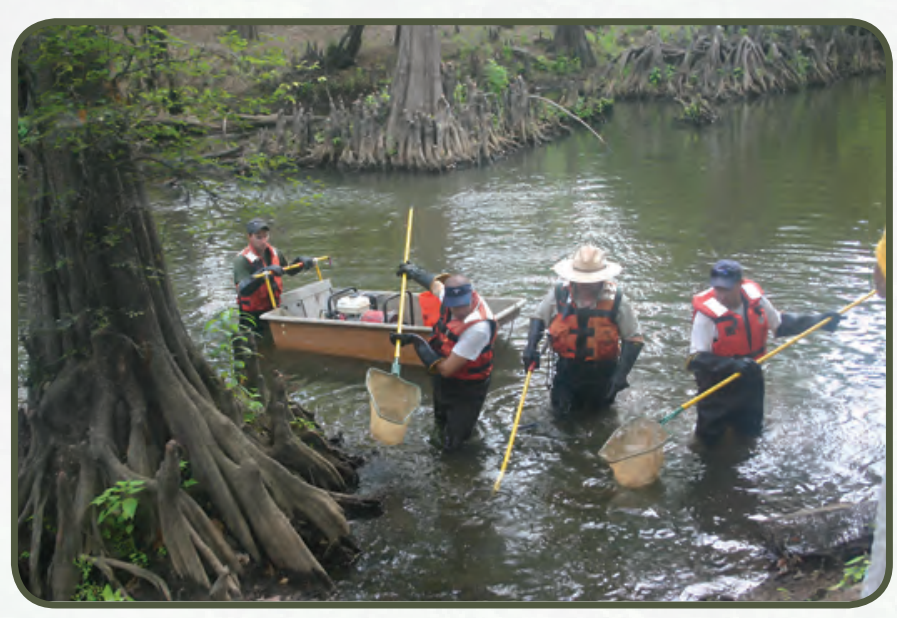

U.S. Geological Survey scientists collecting fish from Big Cypress Creek, Texas, July 27, 2011. Photograph taken by Erin C. Sewell, U.S. Geological Survey.

More species of native minnows, including the ironcolor and emerald shiner, were collected from Little Cypress relative to all other mesohabitats at all sites.

About 14 percent more fish were collected from Big Cypress 02 in 2010 relative to 2011, and about 18 percent fewer fish species were identified in 2011 at this site compared to 2010. Longear sunfish, which was the most abundant fish species collected in 2010, was second to western mosquitofish in 2011.

A total of 15 species and 182 individuals of freshwater mussels were collected. Big Cypress 01 was the most species rich site with 13 species, and washboards were the most abundant species overall. Mussels were not collected from Little Cypress because there was no flow in this stream during the targeted sampling period in 2011.

In the absence of flow during fall 2011, the reach at Black Cypress was reduced to four isolated pools, and the reach at Little Cypress was reduced to three isolated pools. Dissolved oxygen, temperature, $\mathrm{pH}$, and specific conductance data were collected from the pools because it was hypothesized that these conditions would be the most limiting with respect to aquatic life. Dissolved oxygen concentrations ranged from 0.58 milligrams per liter $(\mathrm{mg} / \mathrm{L})$ to $4.79 \mathrm{mg} / \mathrm{L}$ at Black Cypress and from $0.24 \mathrm{mg} / \mathrm{L}$ to $5.33 \mathrm{mg} / \mathrm{L}$ at Little Cypress; both sites exhibited a stratified pattern in dissolved oxygen concentrations along transect lines, but the pattern was less pronounced at Black Cypress.

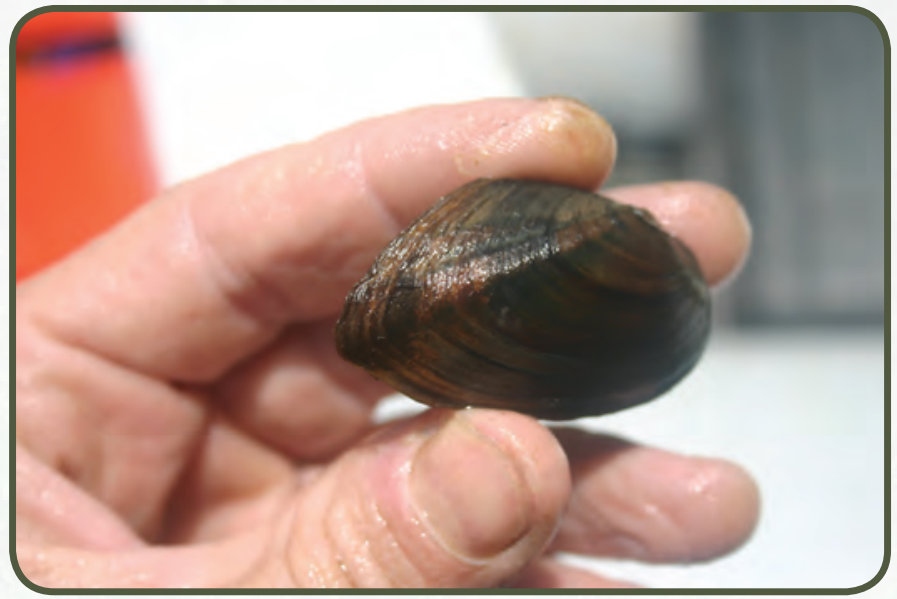

Mussel collected from the Big Cypress Basin in Texas.

\section{This fact sheet is based on the following USGS report:}

Braun, C.L., and Moring, J.B., 2013, Baseline assessment of physical characteristics, aquatic biota, and selected water-quality properties at the reach and mesohabitat scale for reaches of Big Cypress, Black Cypress, and Little Cypress Bayous, Big Cypress Basin, northeastern Texas, 2010-11: U.S. Geological Survey Scientific Investigations Report 2013-5058, 90 p.

\section{References Cited}

Caddo Lake Institute, 2010, Environmental flow regime and analysis recommendations report: accessed on June 30, 2012, at http:/www.caddolakeinstitute.us/ docs/flows/8.10_Recommendations_Report/Cypress SB3_20100826_Main.pdf.

Konrad, C.P., 2010, Monitoring and evaluation of environmental flow prescriptions for five demonstration sites of the Sustainable Rivers Project: U.S. Geological Survey Open-File Report 2010-1065, 22 p.

Pardo, Isabel, and Armitage, P.D., 1997, Species assemblages as descriptors of mesohabitats: Hydrobiologia, v. 344, p. 111-128, accessed May 6, 2013, at http://link.springer.com/content/ pdf/10.1023\%2FA\%3A1002958412237.pdf.

\section{Christopher L. Braun and James B. Moring}

\author{
For additional information, contact \\ Director, Texas Water Science Center \\ U.S. Geological Survey \\ 1505 Ferguson Lane \\ Austin, Texas 78754-4501 \\ http://tx.usgs.gov/ \\ Publishing support provided by \\ Lafayette Publishing Service Center
}

